\title{
Analisis Objektif Pengetahuan Laboratorium Kesehatan Tentang Manfaat Alat Pelindung Diri di Laboratorium Universitas Respati Yogyakarta
}

\author{
Naomi Nisari Rosdewi, Suwarto, Yoseph Emanuel Pati \\ Program Studi Kesehatan Masyarakat, Fakultas IImu Kesehatan, Universitas Respati Yogyakarta \\ Email: naomi.suprayudha@yahoo.co.id
}

\begin{abstract}
Abstrak
Dari studi pendahuluan yang dilakukan di laboratorium kesehatan Universitas Respati Yogyakarta, data atau informasi yang kami dapatkan sangat menjadi masalah sebab dari 5 petugas laboratorium/ laboran yang kami wawancarai, hanya 2 laboran yg rutin menggunakan Alat Pelindung Diri (APD) disetiap kegiatan praktikum di laboratorium. Penelitian ini bertujuan untuk Kajian Analisis objektif pengetahuan petugas laboratoruim kesehatan tentang manfaat alat pelindung diri di laboratorium kesehatan Universitas Respati Yogyakarta. Penelitian ini menggunakan metode kualitatif artinya adalah suatu proses penelitian dan pemahaman yang berdasar pada metodologi yang menyelidiki suatu fenomena sosial dan masalah manusia. Petugas laboran mempunyai pengetahuan yang cukup baik terhadap manfaat penggunaan alat pelindung diri yang terdapat dilaboratorium, secara keseluruhan petugas laboratorium memahami fungsi dari APD dan manfaatnya, penggunaan Alat pelindung diri belum terdapat secara khusus tentang standar pengunaan APD sesuai SOP yang berlaku, kepatuhan Petugas laboran tentang manfaat penggunaan alat pelindung diri sudah sesuai dengan tata tertib yang berlaku dilaboratorium, sarana dan prasana terkait pengunaan alat pelindung diri sudah cukup baik. Petugas laboran mempunyai pengetahuan yang cukup baik terhadap manfaat penggunaan alat pelindung diri yang terdapat dilaboratorium.
\end{abstract}

Kata kunci : petugas laboran, pengetahuan ,alat pelindung diri.

\section{Abstract}

From a preliminary study conducted in the health laboratory of Respati University in Yogyakarta, the data or information we got was very problematic because of the 5 laboratory staff / laboratory assistants we interviewed, only 2 laboratory assistants routinely use Personal Protective Equipment (PPE) in every practicum activity in the laboratory. This study aims to study an objective analysis of the knowledge of health laboratory staff about the benefits of personal protective equipment in the health laboratory of the University of Respati Yogyakarta. This study uses a qualitative method which means it is a process of research and understanding based on a methodology that investigates a social phenomenon and human problems. Laboratory staff have a fairly good knowledge of the benefits of using personal protective equipment in the laboratory, as a whole laboratory staff understands the function of PPE and its benefits, the use of personal protective equipment has not been specifically about the standards for using PPE according to applicable SOPs, compliance of laboratory officers on benefits the use of personal protective equipment is in accordance with the regulations in force in the laboratory, the facilities and infrastructure related to the use of personal protective equipment are quite good. Laboratory staff have a fairly good knowledge of the benefits of using personal protective equipment in the laboratory.

Keywords: laboratory assistant, knowledge, personal protective equipment

http://ejournal.urindo.ac.id/index.php/kesehatan

Article History :

Sumbitted 14 September 2020, Accepted 30 Desember 2020, Published 31 Desember 2020 


\section{PENDAHULUAN}

Lingkungan laboratorium dapat mengandung berbagai dampak negatif yang dapat mempengaruhi derajat kesehatan manusia terutama pekerjaannya. Di era globalisasi dan pasar bebas yang akan berlaku tahun 2020 mendatang, kesehatan dan keselamatan kerja merupakan salah satu prasyarat yang ditetapkan dalam hubungan ekonomi perdagangan barang dan jasa antar negara yang harus dipenuhi oleh seluruh negara anggota, termasuk bangsa Indonesia. Dalam Indonesia tahun 2017 lingkungan yang di harapkan adalah kondusif bagi terwujudnya keadaan sehat. Cara pengendalian dapat dilakukan untuk mengurangi bahaya di lingkungan kerja dimana cara terbaik adalah dengan menghilangkan bahaya atau menutup sumber bahaya tersebut, bila mungkin tetapi sering bahaya tersebut tidak dapat sepenuhnya dan di kendalikan oleh karena itu dibutuhkan usaha untuk pencegahanya dengan menggunakan beberapa alat pelindung diri (Budiono, 2003: 16).

Petugas laboratorium sebagai pekerja salah satu unit dengan bahaya potensial yang cukup tinggi juga mempunyai kemungkinan untuk mengalami resiko bahaya tersebut. Kegiatan laboratorium mempunyai resiko yang berasal dari berbagai macam faktor, yakni fisik, kimia, ergonomi dan psikososial.
Variasi, ukuran, tipe dan kelengkapan laboratorium juga menentukan kesehatan dan keselamatan kerja. Seiring dengan kemajuan IPTEK (Ilmu Pengetahuan dan Teknologi), khususnya kemajuan teknologi laboratorium, maka resiko yang dihadapi petugas laboratorium semakin meningkat. Penerapan sesuai aturan Keselamatan dan Kesehatan Kerja sangat dibutuhkan pada semua pekerjaan yang berguna untuk menghindari hal-hal yang tidak diinginkan, misalnya kecelakaan kerja. Para pekerja terdiri dari orang-orang terdidik dan terlatih. Orang-orang terdidik yang dimaksud salah satunya adalah petugas laboratorium kesehatan masyarakat di Universitas Respati Yogyakarta, karena salah satu pengisi tenaga kerja di dunia kerja adalah Iulusan Perguruan Tinggi, maka proses pembelajaran selama di laboratorium harus menjadi perhatian yang serius guna mendapatkan calon tenaga kerja yang berkualitas, khususnya memahami tentang penerapan pelaksanaan Keselamatan dan Kesehatan Kerja (K3) khususnya pemakaian alat pelindung diri sarung tangan sehingga tidak terjadi hambatan-hambatan langsung maupun tidak langsung dalam pekerjaan, seperti halnya terjadi kecelakaan kerja, kerusakan alat, terhentinya proses kerja, kerusakan lingkungan, dan pengeluaranpengeluaran biaya kecelakaan kerja. 


\section{METODE PENELITIAN}

Penelitian ini menggunakan metode kualitatif artinya adalah suatu proses penelitian dan pemahaman yang berdasar pada metodologi yang menyelidiki suatu fenomena sosial dan masalah manusia. Pada pendekatan ini, peneliti membuat suatu gambaran kompleks, meneliti katakata, laporan terperinci dari pandangan responden, dan melakukan studi pada situasi yang dialami (Creswell, dalam Suprapto, 2010).Bogdan dan Taylor (Dalam Moleong, 2008), mengemukakan bahwa

\section{HASIL DAN PEMBAHASAN}

Lokasi penelitian ini di laboratorium kesehatan Universitas Respati Yogyakarta. Adapun karakteristik informan dalam metodologi kualitatif merupakan prosedur penelitian yang menghasilkan data deskriptif berupa kata-kata tertulis maupun lisan dari orang-orang dan perilaku yang diamati.

Pendekatan kualitatif dipilih dengan tujuan untuk memperoleh pemahaman mendalam atas suatu objek penelitian.Teori awal hanya sebatas membantu pemahaman dalam penyusunan permasalahan agar menjadi lebih terfokus.

penelitian ini dapat dilihat dalam tabel dibawah ini.

Tabel 1. Karakteristik Responden

\begin{tabular}{cllccc}
\hline No & \multicolumn{1}{c}{ Nama } & \multicolumn{1}{c}{ Bagian } & Umur & Pendidikan & Lama Kerja \\
\hline 1 & Nining Wahyuni & Laboran & 48 & S1 & 8 Tahun \\
\hline 2 & Ernita Herawati NK & LKM & 30 & S1 & 3 Tahun \\
\hline 3 & Tutik Martiwi & Skill Lab & 30 & S1 & 10 Bulan \\
\hline 4 & Cahyo Nugroho & Lab. Kes & 30 & S1 & 8 Tahun \\
\hline 5 & Wisnu Jaka P & UPT & 40 & S1 & 8 Tahun \\
\hline 6 & Afilia Ulfah & UPT & 23 & D-III & 3 Bulan \\
\hline 7 & Rois Fatarudin & Laboran & 23 & D-IV & 3 Bulan \\
\hline 8 & Anita Nidtarini & Laboran Gizi & 29 & D-III & 3 Tahun \\
\hline
\end{tabular}

Tabel 2. Distribusi Frekuensi Karakteristik Berdasarkan Usia pada Petugas Laboratoruim Kesehatan Universitas Respati Yogyakarta

\begin{tabular}{cccc}
\hline Usia & F & $\mathbf{n}$ & \% \\
\hline $20-29$ & 3 & 3 & 37,5 \\
$30-39$ & 3 & 3 & 37,5 \\
$40-50$ & 2 & 2 & 25 \\
\hline Total & 8 & 8 & 100 \\
\hline
\end{tabular}




\section{Jurnal Bidang Ilmu Kesehatan}

Berdasarkan tabel 4.2. dapat dilihat bahwa usia responden yaitu terdiri dari 3 responden yang berusia antara 20-29 tahun $(37,5 \%), 3$ responden yang berusia antara 30-39 tahun $(37,5 \%)$, dan 2 responden yang berusia antara $40-50$ tahun (25\%).

Tabel 3. Distribusi Frekuensi Karakteristik Berdasarkan Pendidikan pada Petugas Laboratoruim Kesehatan Universitas Respati Yogyakarta

\begin{tabular}{cccc}
\hline Pendidikan & F & N & \% \\
\hline D-III & 2 & 2 & 25 \\
D-IV & 1 & 1 & 12,5 \\
S1 & 5 & 5 & 62,5 \\
\hline Total & 8 & 8 & 100
\end{tabular}

Berdasarkan tabel 3. dapat dilihat bahwa pendidikan responden yaitu terdiri dari 2 responden Iulusan D-III sebanyak 2 orang
(25\%), 1 responden lulusan D-IV sebanyak 1 orang $(12,5 \%)$, dan 5 responden lulusan S1 sebanyak 5 orang $(62,5 \%)$.

Tabel 4. Distribusi Frekuensi Karakteristik Berdasarkan Lama Kerja pada Petugas Laboratoruim Kesehatan Universitas Respati Yogyakarta

\begin{tabular}{cccc}
\hline Lama Kerja & F & N & \% \\
\hline$<1$ Tahun & 3 & 3 & 37,5 \\
$>1$ Tahun & 5 & 5 & 62,5 \\
\hline Total & 8 & 8 & 100 \\
\hline
\end{tabular}

Berdasarkan tabel 4.4. dapat dilihat bahwa berdasarkan lama kerja yaitu terdiri dari 3 responden yang bekerja kurang dari 1 tahun sebanyak 3 orang responden $(37,5 \%)$

Wawancara mendalam dilakukan terhadap 1 Informasi Kunci yaitu : Kordinator Laborator rium Kesehatan terpadu Fakultas Ilmu Kesehatan, Wawancara selanjutnya dilakukan kepada Informan pendukung sebanyak dan partisipasi terdiri dari : 6 staf petugas laboran yang bekerja di Laboratorium Kesmas, Laboratorium Gizi, Laboratorium Biomedis, laboratorium Keperawatan, laboratorium Kebidanan, dan 5 orang responden yang bekerja lebih dari 1 tahun berjumlah 5 orang responden $(62,5 \%)$. Hal ini dapat dilihat pada grafik di bawah ini.

dan 1 partisipan pada laboratorium Fisioterapi fakultas ilmu kesehatan Universitas Respati Yogyakarta. Kesimpulan dari hasil wawancara tentang Penggunaan Kepatuhan Penggunaan APD di laboratorim didapatkan bahwa : Sarana dan prasara tentang APD yang di gunakan di lab baik laboran dan dosen dan asisten dan mahasiswa sudah tersedia melalui pengajuan pada setiap semester.Hasil 


\section{Jurnal Bidang Ilmu Kesehatan}

Observasi tentang kajian Objektif Pengetahuan Petugas laborantorium kesehtan tentang manfaat alat pelindung diri di laboratorium terpadu fakultas IImu kesehatan Universitas Respati Yogyakarta.Hasil Observasi tentang pengetahuan penggunaan Alat pelindung diri yang digunakan petugas Laboran kesehatan terpadu di FIKes UNRIYO. Dari hasil obeservasi yang dilakukan peneliti didapatkan bahwa petugas laboran ada 9 orang didapatkan bahwa petugas ketika dilakukan observasi bukan dalam keadaan menggunakan APD dikarenakan pada saat peneliti melakukan obeservasi dilaboratorium dalam keadaan sedang tidak ada pratik mahasiswa. Hasil Observasi Tentang Fungsi APD/Manfaat APD terhadap petugas Laboran kesehatan terpadu di FIKes UNRIYO. Dari hasil observasi yang dilakukan oleh peneliti didapatkan bahwa rata-rata petugas laboran memahami tentang fungsi dalam menggunakan alat pelindung diri yang ada dilaboratorium dengan menunjukan APD apa saja yang digunakan di laboratorium masing-masing pada saat peneliti melakukan observasi secara langsung selain melakukan wawancara secara langsung, selain itu hasil observasi juga menujukan beberapa tata tertib umum ketika sedang melakukan paraktik baik, di laboratorium kesmas, laboratorium biomedis, laboratorium keperawatan dan kebidanan. Hasil Observasi Peneliti
Tentang Penggunaan APD apakah sudah sesuai dengan SOP yang ada dilaboratorium. Dari hasil observasi yang dilakukan peneliti apakah APD yang digunakan Sudah sesuai dengan penggunaan nya pada saat petugas laboran ,dosen, asisten dosen dan mahasiswa pada saat melakukan pratik apakag sudah sesuai SOP atau belum, petugas laboran mengatakan sudah sesuai dengan SOP yang dipasang di tata tertip laboratorium namun memang mereka mengakui bahwa penggunaan APD belum mempunyai SOP secara khusus terkait dengan Penggunaan APD : seperti SOP tentang penggunaan jaslab,masker dan handcun. Hasil Observasi Tentang Kepatuhan menggunakan APD petugas laboran kesehatan terpadu. Dari hasil observasi yang dilakukan peneliti baik petugas laboran,dosen dan mahasiswa sudah menggunakan APD pada saat pratik di laboratorium namun terkadang petugas,asdos dan mahasiswa merasa tidak nyaman dalam menggunakan atau momen tertentu ketika praktek sudah selesai APD dilepaskan. Sarana prasana tentang APD peratan APD yang di gunakan di laboratorium. Dari hasil observasi secara langsung yang dilakukan peneliti melihat pencatan dan pendokumentasian mengenai sarana dan prasara APD yang ada diruang laboratorium pada prinsip memenuhi karena setiap semesternya dilakukan pengajuan kepada isntitusi untuk 
pembelian APD yang digunakan pada saat melakukan praktik dilaboratorium sesuai jadwal yang sudah dibuatkan. Hasil Studi Dokumen dan Pembahasan. kajian hasil analisi Literasi studi dokumen mengenai pengetahuan tentang manfaat APD petugas Laboran. Menurut Peneliti : mengenai pengetahuan petugas laboran sudah cukup baik terbukti pada saat peneliti melakukan wawancara mereka langsung tanggap terhadap APD yang sering didigunakan dilaboratorium pada saat berlangsung namun memang belum dapat menyebutkan secara detail dan rinci hanya terbatas pada APD yang sering digunakan di laboratorium masing-masing.

Sedangkan menurut notoadmojo tahun 2012 :mengatakan bawah : Pengetahuan merupakan hasil dari tahu dan ini terjadi setelah orang melakukan penginderaan terhadap suatu objek tertentu. Pengetahuan berperan untuk terbentuknya tindakan seseorang (overt behavior) (Notoatmojo, 2012: 1). Pengetahun atau kognisi yang ada pada seseorang diterima melalui indera. Indera yang paling banyak menyalurkan pengetahuan ke dalam otak adalah mata. Kurang lebih $75 \%$ sampai $87 \%$ dari pengetahuan manusia diperoleh melalui mata (Notoatmojo, 2012: 1). Pengetahuan yang dicakup dalam domain kognitif ada 6 tingkatan (Notoatmojo, 2012: 3): 1.Tahu (know) artinya mengingat suatu materi yang telah dipelajari sebelumnya. Termasuk kedalam tingkat ini adalah mengingat kembali (recall) terhadap suatu yang spesifik dari seluruh bahan yang dipelajari atau rangsangan yang telah diterima. Oleh sebab itu "tahu" merupakan tingkat pengetahuan yang paling rendah. 2.Memahami (comprehension) disini diartikan sebagai suatu kemampuan untuk menjelaskan secara benar tentang objek yang diketahui dan dapat menginterpretasikan materi tersebut secara benar. 3.Aplikasi (application) maksudnya sebagai penggunaan hukum, rumus, metode, prinsip dan sebagainya dalam situasi yang lain. Misalnya dapat menggunakan prinsipprinsip siklus pemecahan masalah kesehatan yang diberikan.

4. Analisis (analysis) adalah suatu kemampuan untuk menjabarkan materi atau suatu objek kedalam komponen, tetapi masih dalam suatu struktur organisasi tersebut, dan masih ada kaitannya satu sama lain. Kemampuan analisa dapat dilihat dari penggunaan kata kerja, seperti dapat menggambarkan, membedakan, memisahkan, mengelompokkan.

5.Sintesis (syinthesis) yaitu suatu kemampuan untuk meletakkan atau menghubungkan bagian-bagian di dalam suatu bentuk keseluruhan yang baru atau formulasi baru. 
6.Evaluasi (evaluation) hal ini berkaitan dengan kemampuan untuk melakukan penilaian terhadap suatu materi. Penilaian itu berdasarkan kriteria yang telah ada.

Kajian hasil analisi Literasi studi dokumen mengenai Fungsi/manfaat APD petugas Laboran. Menurut Peneliti : Secara Umum hampir semua petugas laboran memahami tentang fungsi dan manfaat APD secara baik namun hanya saja laboran mengunakan APD sesuai fungsinya berdasarkan tata tertib yang berlaku dan berdasarkan buku panduan petunjuk praktikum dilaboratorium. Alat pelindung diri merupakan seperangkat alat yang digunakan tenaga kerja untuk melindungi sebagian atau seluruh tubuhnya dari adanya bahaya atau kecelakaan kerja. APD tidak secara sempurna dapat melindungi tubuhnya, tetapi akan dapat mengurangi tingkat keparahan yang mungkin terjadi. Pengendalian ini sebaiknya tetap dipadukan dan sebagai pelengkap pengendalian teknis maupun pengendalian administratif (A.M. Sugeng Budiono, 2003: 329). Menurut Kemenkes Tahun 2010 : Manfaat APD bagi perusahaan adalah:
1) Meningkatkan
produksi perusahaan dan efisiensi optimal 2) Menghindari hilangnya jam kerja akibat absensi tenaga kerja

3) Penghematan biaya terhadap pengeluaran ongkos pengobatan serta pemeliharaan kesehatan tenaga kerja Alat pelindung diri (APD) adalah seperangkat alat keselamatan yang digunakan oleh pekerja untuk melindungi seluruh atau sebagian tubuhnya dari kemungkinan adanya pemaparan potensi bahaya lingkungan kerja terhadap kecelakaan dan penyakit akibat kerja (Tarwaka, 2008). Kajian hasil analisis studi dokumen mengenai Pengunaan APD apakah sesuai dengan SOP yang berlaku di laboran. Menurut Peneliti : Penggunaan APD sesuai dengan tata tertib yang berlaku laboran sudah baik hanya saja secara khusus belum ada kebijakan dan kajian mnegenai penggunaan APD yang sesuai dengan SOP karena memang belum ada penggunaan secara tersertandar dilingkungan laboran. Sedangan Menurut A.M. Sugeng Budiono (2003), alat pelindung diri yang telah dipilih hendaknya memenuhi ketentuan sebagai berikut :

1. Dapat memberikan perlindungan terhadap bahaya

2. Berbobot ringan

3. Dapat dipakai secara fleksibel (tidak membedakan jenis kelamin)

4. Tidak menimbulkan bahaya tambahan

5. Tidak mudah rusak

6. Memenuhi standar yang ada 
7. Pemeliharaan mudah

8. Penggantian suku cadang mudah

9. Tidak membatasi gerak

10. Rasa "tidak nyaman" tidak berlebihan (rasa "tidak nyaman" tidak mungkin hilang sama sekali, namun diharapkan masih dalam batas toleransi)

11. Bentuk cukup menarik

Kajian hasil analisis studi dokumen mengenai kepatuhan Mengunakan APD petugas laboran dalam setiap praktikum dilaboratorium. Menurut Peneliti: berdasarkan studi dokomen dilapangan kepatuhan petugas dilaoratorium sudah patuh sudah sesuai tata tertib yang berlaku di laboratorium hanya saja belum terdapat peraturan secara khusus tata tertib tentang kepatuhan penggunaan alat lindung diri harus dibikin kebijakan secara baik dan detail terhadap kebijakan tentang komitment dan kepatuhan petugas laboran,dosen dan mahasiswa. Dapat dibandingkan secara khusus dengan kebijakan yang di buat oleh kemenkes tahun 2010 langkah-langkah diantaranya adalah:

a. Menyusun kebijaksanaan penggunaan dan pemakaian APD secara tertulis, serta mengkomunikasikannya kepada semua tenaga kerja/praktikan dan tamu yang mengunjungi perusahaan/ laboratorium tersebut.

b. Memilih dan menempatkan jenis APD yang sesuai dengan potensi bahaya yang terdapat di tempat kerja/ laboratorium.

c. Melaksanakan program pelatihan penggunaan APD untuk meyakinkan tenaga kerja/ laboratorium agar mereka mengerti dan tahu cara menggunakannya. Untuk kegiatan praktikum di laboratorium dapat berupa penjelasan pentingnya dan cara penggunaan APD.

d. Menerapkan penggunaan dan pemakaian APD serta pemeliharaannya secara berkala.

Sedangkan peraturan lainnya yang mengatur tentang APD salah satunya adalah Peraturan Menteri Tenaga Kerja dan Transmigrasi No. Per 03/Men/1982 tentang Pelayanan Kesehatan Kerja. Permenakertrans tersebut mengatur APD sebagimana termuat pada Pasal 1 ayat (2) dan Pasal 2 ayat (1).

a. Pasal 1 ayat (2) tentang Tujuan Pelayanan Kesehatan Kerja:

"Melindungi tenaga kerja terhadap setiap gangguan kesehatan yang timbul dari pekerjaan atau lingkungan kerja" 
b. Pasal 2 ayat (1) tentang Tugas Pokok Pelayanan Kesehatan Kerja:

"Memberikan nasehat mengenai perencanaan dan pembuatan tempat kerja" Pemilihan alat pelindung diri yang diperlukan dan zat gizi serta penyelenggaraan makanan ditempat kerja".

Kajian hasil analisis studi dokumen mengenai sarana prasarana peralatan APD petugas laboran dalam setiap praktikum dilaboratorium. Studi Dokuentasi mengenai Studi sarana prasarana alat pelindung diri dilaboratorium sudah ada pencatatan baik masuk maupun pengeluaran penggunaan APD berdasarkan pengajuan dari petugas laboran kepada institusi untuk digunakan sebagai APD pada saat melakukan praktikum. Bila dibandingan menurut kemenkes tahun 2010 Manfaat laboratorium bagi

\section{SIMPULAN}

1. Petugas laboran mempunyai pengetahuan yang cukup baik terhdap manfaat penggunaan alat pelindung diri yang terdapat dilaboratorium.

2. Secara keseluruhan petugas laboratorium memahami fungsi dari APD dan manfaatnya. pendidikan tenaga kesehatan setidaknya mencakup hal sebagai berikut (Kemenkes RI, 2010):

1) Merupakan unsur penunjang dalam melaksanakan tercapainya kompetensi peserta didik sesuai kurikulum.

2) Untuk meningkatkan proses pembelajaran di laboratorium yang teratur dan berkelanjutan, sehingga dapat meningkatkan mutu pendidikan.

3) Menyiapkan peserta didik menjadi terampil sebelum ke lahan (Rumah Sakit, Puskesmas, Rumah Bersalin, Laboratorium, dan komunitas)

Sehingga setiap melakukan kegiatan praktikum harus didukung sarana dan prasana yang baik yang digunakan pada saat praktik berlangsung untuk menghindarkan petugas, dosen, asdoos dan mahasiswa supaya tidak terjadi sesuatu yang tidak di inginkan.

3. Penggunaan Alat pelindung diri belum terdapat secara khusus tentang standar pengunaan APD sesuai SOP yang berlaku

4. Kepatuhan Petugas laboran tentang manfaat penggunaan alat pelindung diri sudah sesui dengan 
tata tertib yang berlaku

dilaboratorium

\section{DAFTAR PUSTAKA}

A.M. Sugeng Budiono. 2003. Bunga Rampai Hiperkes dan KK Higiene Perusahaan Ergonomi Kesehatan kerja Keselamatan Kerja. Semarang: Universitas Diponegoro.

A Partanto, Pius dan M. Dahlan Al Barry. 2001. Kamus IImiah Populer. Surabaya: Arkola.

Apriliani Siburian. 2008. "Hubungan Penggunaan Alat Pelindung Diri (APD) terhadap Keselamatan Kerja Perawat IGD RSUD Pasar Rebo Tahun 2012". Skripsi. Jakarta: Universitas Indonesia.

Azwar, Saifuddin. 2014. Metode Penelitian.

Yogyakarta: Pustaka Pelajar.

Kementerian Kesehatan RI. 2010. Standar Laboratorium Kebidanan Pendidikan Tenaga Kesehatan. Jakarta: Bakti Husada.

Moleong, Lexy J. 2014. Metodologi Penelitian Kuantitatif. Bandung: Remaja Rosdakarya.

Mulyanti S, Putri HM. 2011. Pengendalian Infeksi Silang di Klinik Gigi. Jakarta: EGC.

Notoatmodjo, Soekidjo. 2011. Kesehatan Masyarakat. Jakarta: Rineka Cipta.
5. Sarana dan prasana terkait pengunaan alat pelindung diri sudah cukup baik.

Prastowo, Andi. 2012. Metode Penelitian Kualitatif dalam Perspektif Rancangan Penelitian. Yogyakarta: Ar-Ruzz Media.

Soekidjo Notoatmodjo. 2012. Metodologi Penelitian Kesehatan. Jakarta: Rineka Cipta.

Sugiyono. 2012. Metode Penelitian Pendidikan. Bandung: Alfabeta.

Sugiyono. 2013. Memahami Penelitian Kuantitatif. Bandung: Alfabeta.

Sugiyono. 2014. Statistika untuk Penelitian. Bandung: Alfabeta.

Suharsimi Arikunto. 2013. Prosedur Penelitian Suatu Pendekatan Praktik. Jakarta: Rineka Cipta.

Tarwaka. 2008. Keselamatan dan kesehatan Kerja Manajemen dan Implementasinya di Tempat Kerja. Surakarta: Harapan Press.

Wahyu Wijayanto. 2015. "Hubungan Motivasi Perawat dengan Perilaku Pemakaian Alat Pelindung Diri Saat Melakukan Kemoterapi di Ruang Rawat Inap RSUD Dr. Moewardi." Skripsi. Surakarta: STIKES Kusuma Husada. 